\title{
Rastros da memória e fagulhas da criação em Cinzas do norte
}

\author{
Roniere Menezes* \\ Izabel Fonseca Sá**
}

\begin{abstract}
Resumo
O presente trabalho objetiva investigar o emprego do conceito de memória no processo criativo do romance Cinzas do norte, de Milton Hatoum. São estabelecidas relações entre a vida do autor e a sua obra, a partir do conceito de "biografema" desenvolvido por Roland Barthes. Relações entre vivência, memória, esquecimento e invenção serão abordadas, assim como diálogos entre literatura, memória, corpo e História contemporânea do Brasil. A estrutura do enredo de Cinzas do norte reflete a perspectiva de trabalhos fragmentários com a memória. A mescla entre cartas, relatos e foco narrativo reconfiguram modalidades mais tradicionais do gênero memorialístico. Todavia, o discurso ainda se prende a um posicionamento ligado, em última instância, à voz do narrador, responsável este por reorganizar os diversos textos e gêneros que se alternam no livro.
\end{abstract}

Palavras-chave: Milton Hatoum. Literatura. Arte. Memória. Política.

\section{Biografemas}

Este ensaio visa a refletir, entre outros aspectos, sobre a importância do conceito de memória em Cinzas do norte, de Milton Hatoum. Nesse sentido, Hatoum assinala: "Muito do que escrevi é uma tentativa de recriar um pequeno mundo de seres e situações num lugar também inventado, mas com referências fortes à cidade em que nasci e morei muitos anos." (HATOUM apud CURY, 2002, p. 309). De acordo com o escritor, torna-se "difícil separar essa experiência da obra escrita, mas aquela é apenas um ponto de partida para o que vem depois. A passagem da vida à literatura talvez seja um dos enigmas da arte da ficção." (HATOUM apud CURY, 2002, p. 309).

Entre os teóricos que se propuseram repensar - sob novos parâmetros - a figura do autor está Roland Barthes. Em algumas de suas obras posteriores ao texto em

* Centro Federal de Educação Tecnológica de Minas Gerais (CEFET) . Professor do Curso de Letras e da Pós-graduação em Estudos de Linguagens do CEFET-MG. Doutor em Literatura Comparada pelo Programa de Pós-graduação em Estudos Literários da Faculdade de Letras da UFMG.

** Centro Federal de Educação Tecnológica de Minas Gerais (CEFET-MG). Mestranda em Estudos de Linguagens do CEFET-MG. 
que declara a morte do autor, o ensaísta trabalha com a noção de "biografema". No prefácio de Sade, Fourier, Loyola, por exemplo, Barthes escreve sobre "uma volta amigável do autor":

$\mathrm{O}$ autor que volta não é por certo aquele que foi identificado por nossas instituições (história e ensino da literatura, da filosofia, discurso da Igreja); nem mesmo o herói de uma biografia ele é. $\mathrm{O}$ autor que vem do seu texto e vai para dentro da nossa vida não tem unidade; é um simples plural de "encantos", o lugar de alguns pormenores tênues, fonte, entretanto, de vivos lampejos romanescos, um canto descontínuo de amabilidades, em que lemos apesar de tudo a morte com muito mais certeza do que a epopeia de um destino; não é uma pessoa (civil, moral), é um corpo. (BARTHES, 2005, p. XVI).

Barthes denomina "biografema" os rastros de experiência pessoal que o autor recupera em suas obras: "Porque, se é necessário que, por uma dialética arrevesada, haja no Texto, destruidor de todo sujeito, um sujeito para amar, tal sujeito é disperso, um pouco como as cinzas que se atiram ao vento após a morte". (BARTHES, 2005, p. XVI e XVII).

O conceito de biografema de Barthes contribuirá com nossa investigação sobre o romance Cinzas do norte. Não há dúvida de que essa obra seja um romance ficcional; entretanto, nela podem ser encontrados alguns ecos da vida do autor. A principal razão dessa ressonância da vida de Hatoum em sua obra deve-se ao seu próprio processo criativo, no qual a evocação da memória está presente. Conforme Hatoum:

A memória participa disso na medida que provoca um retorno imaginário, alguma lacuna que a gente não pode mais recuperar. A memória é o único desafio do passado, de prestar contas com ele, seja através de uma imagem, de uma história oral ou escrita. É como se, diante de uma ruína, a gente tentasse imaginar a casa antes de sua demolição ou destruição; quem morava ali, como e em que tempo viveram aquelas pessoas, como elas se relacionavam entre si etc. O ponto de partida são essas ruínas, e a ficção é uma tentativa de imaginar a sua história, reconstruí-la e retornar ao que já não existe mais. (HATOUM apud CRISTO, 2007, p. 25).

Em Cinzas do norte, o narrador-personagem Lavo (Olavo), ao rememorar o período da infância e da adolescência junto ao amigo Mundo (Raimundo), recupera a memória da cidade de Manaus, em consonância com reminiscências do próprio 
autor do livro. O texto revela riqueza de detalhes e vasto conhecimento a respeito de aspectos ambientais e histórico-culturais do espaço descrito. Apesar de Hatoum ter deixado a sua terra natal ainda na adolescência, o fato de todas as suas obras serem ambientadas no estado do Amazonas estabelece um forte nexo entre obra e autor. Cumpre lembrar que o colégio em que o narrador Lavo estuda é o mesmo em que o autor estudou em Manaus, o Colégio Pedro II. Devemos salientar que Manaus aparece no livro com as mesmas marcas de transformações modernizantes ocorridas em outras metrópoles do Brasil durante o século XX.

O livro, mesclando relatos e cartas ao discurso do narrador, é organizado de modo polifônico, demonstrando, nesse sentido, encontros e desencontros das personagens, tensões familiares e algumas diferenças de perspectivas. Paralelamente à história de desintegração familiar, o enredo traz um fundo histórico relativo ao período da ditadura militar no Brasil, bastante conhecido pelo autor do livro. Nota-se, pela leitura de Cinzas do norte, não apenas a retomada de imagens ligadas a certo período histórico do país, o texto também evoca comportamentos, ideologias, imaginários que marcaram profundamente a vida sociocultural brasileira de meados do século XX.

Cinzas do norte inicia-se com um breve preâmbulo em que Lavo explica como uma carta enviada por Mundo, supostamente escrita em seu leito de morte, despertou-lhe as recordações: "Uma carta sem data, escrita numa clínica em Copacabana, aos solavancos e com uma caligrafia miúda e trêmula que revelava a dor do meu amigo" (HATOUM, 2013, p. 9). A carta deflagra as lembranças do narrador e o impulsiona a contá-las: "Uns vinte anos depois, a história de Mundo me vem à memória com a força de um fogo escondido pela infância e pela juventude" (HATOUM. 2013, p. 9). O livro, "escrito" pelo narrador Lavo, apresenta-se como tentativa de reconstituição tanto da vida do amigo Mundo como de um drama familiar.

No centro da narrativa de Cinzas do norte está o conflito entre Mundo e seu pai, Trajano Mattoso - Jano -, um empresário amazonense de personalidade autoritária que não aceita a postura "rebelde" do filho. Este sonha seguir carreira artística em vez de administrar os negócios da família. A bela Alícia, mulher de Jano, destaca-se como amparo amoroso do filho, dentro do lar. Enquanto Mundo faz parte de uma família milionária, Lavo é órfão, criado pela tia costureira, Ramira, e pelo tio Ranulfo. Segundo Daniel Piza, 
o irmão de Ramira, Ranulfo, o tio Ran, é outro desses personagens machadianos de Hatoum, um desocupado, um "cigano" que vive entre farras e livros e não quer trabalho nem responsabilidade, embora queira dinheiro e mulheres. (...) É no atrito entre essas duas famílias de classes sociais distintas que a trama desliza, entre idas e vindas, dúvidas e lembranças. (PIZA, 2005, p. 1-2)

Em sua tarefa de escrita literária, ao se lembrar de Mundo, Lavo destaca uma frase que lhe fora enviada pelo amigo, em um cartão postal: "Ou a obediência estúpida, ou a revolta.” (HATOUM, 2013, p. 10). Essa frase pode ser interpretada como o tema central de toda obra, refletindo a personalidade de Mundo, as tensas relações deste com o pai e com as instâncias de poder. Além disso, a frase pode representar o conflito interno de Lavo em relação a sua própria postura diante dos lugares de opressão.

A narrativa de Lavo, que compreende a maior parte da obra, é contada a partir das vésperas do golpe militar de 1964, com algumas digressões para a sua infância, e segue até meados da década de 1980. Lavo e seu tio Ranulfo aparecem como principais focos de enunciação no texto. Apesar de o livro ser interpolado por cartas de Ranulfo e de Mundo, a perspectiva de Lavo prevalece como condutora do enredo, mesmo que tangenciada por diversos olhares, diversas percepções. As cartas do tio Ranulfo, que têm Mundo como destinatário, correspondem a um tempo anterior ao nascimento de Mundo e Lavo. A carta escrita por Mundo antes de morrer corresponde a uma época mais próxima ao tempo da enunciação de Lavo. Deve ser ressaltado que muito do que Lavo narra foi revelado a ele por seu tio Ranulfo e por sua tia Ramira, mas também por Alícia, Arana, por Macau e Naiá - empregados da família Mattoso -, ou seja, refere-se a memórias alheias. Episódios vivenciados por Lavo, na adolescência, e conversas entre o narrador e algumas personagens são retomados no processo narrativo.

\section{Retratos da noite sombria}

Em 2002, Milton Hatoum escreveu um artigo intitulado "Um certo oriente", para a revista Litterature d'America, em que prenuncia a temática de Cinzas do norte, publicado em 2005. Nesse artigo, Hatoum relaciona a produção do seu romance Relato de um certo oriente às suas memórias. Começa evocando certa noite sombria de 1977 que se tornou para ele "epílogo simbólico dos anos 70 do Brasil.” (HATOUM, 2002, p. 5). 
$\mathrm{Na}$ noite em questão, Hatoum e amigos procuravam um lugar para se esconderem da polícia, que invadia o campus universitário da PUC-SP durante um ato contra o regime militar. Dois anos depois, Hatoum foi para Espanha como bolsista, e a vontade de escrever um romance político começou a surgir. A intenção inicial era escrever um livro sobre o biênio do terror 68-69 que testemunhara quando era estudante em Brasília e, posteriormente, quando era universitário em São Paulo. Entretanto, como mostra Hatoum, a sua proximidade com o tempo narrado, tornava o seu texto "uma crônica dos acontecimentos recentes", os eventos estavam "talvez vivos demais" na memória do escritor. Este escreve:

Não conseguia imprimir no texto o poder de fingir, que é o mais inofensivo dos poderes, mas que numa obra de ficção me parece fundamental. Esse poder de fingir, de passar a impressão de verdade tem a ver com muitas coisas: a relação do tempo de discurso com o tempo da história, a construção das personagens, a organização do enredo, com seus saltos temporais, digressões, etc. Para escrever um quase presente (os anos 70), dificilmente eu teria conseguido o efeito do choque, o sobressalto de que fala Baudelaire, ou a memória involuntária tanto citada por Proust. (HATOUM, 2002, p. 6).

Hatoum seguiu, então, outro caminho: buscou, em um tempo mais distante, a infância nos anos 50 e 60, as lembranças e as vozes para as construções de suas narrativas. Assim surgiu o seu primeiro romance Relato de um certo oriente (1989), seguido de Dois irmãos (2000). Em 2005, Hatoum publicou Cinzas do norte, narrativa que compreende o período da década de 1950 até a década de 1980. Como o período em que o Brasil foi comandado pelo regime militar refletese em diversas passagens do livro, pode-se inferir que as lembranças daquela noite sombria de 1977 - símbolo, para o autor, de todo um período repressivo - acabam propiciando o processo criativo de Cinzas do norte. De acordo com Hatoum,

(...) outra vez voltamos aos movimentos da memória: hoje, só podemos narrar o que nos aconteceu em 22 de setembro de 1977 se inventarmos um pouco (ou muito) daquela noite nefasta. E isso porque "eu" que narra no presente é um índice que permanece constante, mas essa constância é ambígua, pois o narrador era "diferente" do que é hoje. Poderia não mencionar a data da invasão e da repressão policial, e fazer daquela noite uma síntese de todas as noites dos anos 70, uma noite longa, de pesadelos sucessivos, uma tentativa de alegorizar uma fatia da história durante o regime militar. (HATOUM, 2002, p. 16). 
A partir desse trecho do artigo de Hatoum, pode-se inferir que, em Cinzas do norte, a vivência do autor no período da ditadura torna-se diluída e reelaborada artisticamente na construção literária, em forma de biografemas. A atmosfera de violência, as relações político-econômicas entre empresários e militares, a transformação do espaço rumo a um ideal de ordem e progresso, a censura, o medo e a tortura são algumas das características do período bem evidentes ao longo da trama. Nesse sentido, podemos citar a passagem em que "as aulas da faculdade de direito foram canceladas em protesto contra o assassinato de um aluno da Escola Politécnica da Universidade de São Paulo.” (HATOUM, 2005, p. 122). Fatos ocorridos no Sudeste chegam ao Norte encorajando jovens a se posicionarem contra o sistema político instaurado no país. Logo no início do livro, esse espectro do período militar já aparece na obra. A própria relação entre Lavo e Mundo recomeça, após os encontros na infância, ancorada em uma época turbulenta: "Só fui tornar a encontrá-lo em meados de abril de 1964, quando as aulas do ginásio Pedro II iam recomeçar depois do golpe militar.” (HATOUM, 2005, p. 12).

Rastros da memória surgem em diversos momentos da narrativa. Com retalhos, sobras de tecidos que Ramira costurava, Ranulfo e Mundo criaram uma intervenção artística intitulada "Campo de cruzes" no bairro Novo Eldorado, inaugurado durante o regime militar. Por criticar o descaso com que as autoridades tratavam os moradores do pobre local, Lavo e Ranulfo são perseguidos por militares, com o apoio do próprio Jano. Podemos supor, a partir do artigo de Hatoum, ter ocorrido na cena do "Campo de Cruzes", uma retomada da situação real vivenciada por ele no Campus da PUC. Cumpre assinalar a semelhança entre a sonoridade dos significantes "Campo de Cruzes e "Campus da PUC".

Muitas vezes, os escritores tomam, como ponto de partida para algum enredo ou parte deste, um acontecimento real que é reelaborado pela imaginação, pela fabulação. Retiram da situação vivida não a descrição fiel, não pretendem decalcála em novo contexto, mas retomam o que resta, a percepção, no caso, ligada a momentos de medo, apreensão, perigo; instantes revividos por Mundo e Ranulfo ao se esconderem no mato e pressentirem a chegada da polícia. Mundo, desta vez ainda consegue fugir, mas Ranulfo é pego e duramente espancado. A tradução de sensações para espaços e tempos distintos é traço de importantes narrativas ligadas ao trabalho com a memória. Segundo Georges Didi-Huberman, é "provável que não haja história interessante senão na montagem, no jogo rítmico, na contradança das cronologias e dos anacronismos." (DIDI-HUBERMAN, 2015, p. 42). 
A formação literária de Hatoum oferece pistas para a análise de Cinzas do norte. No artigo "Um certo oriente", citado anteriormente, o escritor se refere à memória involuntária de Proust, necessária para "o poder de fingir", existente em uma obra de ficção (HATOUM, 2002, p. 6). Como dissemos, as lembranças de Lavo, adormecidas durante vinte anos, são despertadas pela potência virtual da carta enviada a ele por Mundo. Cumpre observar que, se a memória involuntária revelou-se necessária para a construção da narrativa da personagem Lavo, também se mostrou importante para o processo criativo de Milton Hatoum. Assim, a invenção literária existente por meio da evocação da memória apresenta-se metaforizada na construção da narrativa de Lavo. Em entrevista, Hatoum assegura ser proustiano "até o tutano" e observa:

(...) A memória mais fértil para a literatura é a cena que nos vem à mente de um modo súbito e impreciso, que nem uma faísca. Não é a memória vigiada, da lembrança refletida e consciente da inteligência. Beckett, num ensaio sobre Proust, chamou a memória involuntária de explosiva, uma espécie de mágico rebelde que extrai o útil e o previsível da lembrança pontual (HATOUM apud CHIARELLI, 2007, p. 76).

O narrador de Cinzas do norte conta a história de seu amigo a partir do que leu e ouviu, a partir de suas lembranças e percepções, modificadas pela passagem do tempo. Como nos mostra Jeanne Marie Gagnebin, em Lembrar escrever esquecer, se a memória é lembrança, paradoxalmente, também é esquecimento. A memória nunca se revela totalmente, mas sim por meio de fragmentos, rastros. $\mathrm{O}$ rastro, conforme a autora, "inscreve a lembrança de uma presença que não existe mais e que sempre corre o risco de se apagar definitivamente." (GAGNEBIN, 2009, p. 44).

Ao escolher um narrador que também rememora, Hatoum cria um duplo espaço para a imaginação, proporcionado pelas lacunas de sua memória e pelas lacunas da memória de Lavo. No espaço do esquecimento, a imaginação se manifesta propiciando lugar para o surgimento de outras vozes. Na intenção de contar a história de Mundo, Lavo suplementa o seu discurso com as cartas de tio Ranulfo, de Mundo, com as lembranças e relatos de tia Ramira e de outras personagens. 


\section{0 escritor advogado e 0 artista out-law}

Em relação ao fato de a narrativa de Cinzas do norte ser feita de restos, podemos nos lembrar do episódio em que, já quase ao final do livro, Lavo se lembra do dia em que presenciou a demolição da casa de Jano e Alícia. O local havia sido vendido e, lembrando um grande esqueleto, parecia se transformar em ruína. Em intertexto com o livro Crônica da casa assassinada, de Lúcio Cardoso, a imagem de corrosão vislumbrada no palacete metaforiza as relações desagregadas, a decadência financeira, a interrupção de sonhos. O narrador Lavo entrou no local e recolheu um pequeno pedaço da pintura do teto:

Vi pela última vez $A$ glorificação das belas-artes na Amazônia no teto da sala: com cortes de formão e marteladas os operários a destruíram. O estuque caiu e se espatifou como uma casca de ovo; no assoalho se espalharam cacos de musas, cavaletes e liras, que os homens varriam e jogavam no jardim cheio de entulho. (...) Apanhei só o pincel com a assinatura de De Angelis, como lembrança. (HATOUM, 2005, p. 224-225).

De acordo com Ivete Sánches, o verbo colecionar tem origem latina no termo colligere (recolher, reunir). Segundo a autora, há uma relação entre o ato de ler, legere (colher, colecionar, ler) ou escrever e o ato de colecionar (SÁNCHEZ, 1999, p. 13). Cinzas do norte aproxima a figura do autor à do narrador e à do colecionador. Lavo recolheu, colecionou informações, relatos, revisou-os e associou-os à escrita de seu livro.

Podemos também relacionar a profissão de Lavo - advocacia - à do escritor que almeja, por meio de seu discurso, convencer, criar pactos com o leitor. Como pode ocorrer em um processo jurídico, o narrador-personagem ouve testemunhos de diversas personagens, cruzando informações em busca de sentidos que fortaleçam seus argumentos, mesmo que no campo literário esses sejam, por natureza, mais fluidos e abertos.

Em sua vida profissional, Lavo deixa o escritório de advocacia em que atuava para trabalhar em prol de pessoas desassistidas, homens pobres, muitas vezes abandonados nas cadeias, tomados como "vida nua", destituídas de dignidade humana (AGAMBEN, 2002). Desse modo, revela uma posição política plena de ideais que terminam por aproximá-lo de Mundo. 
Cinzas do norte mescla história do Brasil relativa ao período do regime militar, histórias de uma comunidade, faces da intimidade familiar, da vida amorosa e empresarial; conjuga espaços subjetivos a espaços concretos de Manaus, Rio de Janeiro, Londres, etc. Temporalidades distintas aproximam-se entre relatos, cartas e a própria escrita de Lavo. Imagens do trabalho aparecem tanto nos empreendimentos de Jano e do coronel Zana como na lida diária da costureira Ramira. Esta funciona na narrativa como símbolo da retenção, do ordenamento, da medida precisa, entrando constantemente em choque com as posturas mais libertárias tanto do irmão Ranulfo quanto de Alícia. Deve-se notar, nesse sentido, a estranha e velada atração existente entre Ramira e Jano, em oposição à explícita atração existente entre a sedutora Alícia e o boêmio Ranulfo, seu amante. Cumpre ainda salientar o contraste entre a figura de Jano - o pai opressor de Mundo - e Ranulfo - que acolhe o menino e trata-o como filho, acreditando ser seu verdadeiro pai. A questão da paternidade de Mundo, no entanto, só é resolvida ao final do enredo.

Notamos, no livro, a existência de uma tensão entre espaços de controle e espaços de descontrole, fluidos, libertários. O empresário Jano desejava implantar um projeto arrojado de desenvolvimentismo na Amazônia, almejava "civilizar" a região. Impunha normas disciplinares, regras de trabalho, comportamento religioso, desconsiderando totalmente o ideário existencial, o talento artístico do filho e tudo aquilo que sua criação representava. Desde a infância de Mundo, Jano buscava impingir-lhe disciplina e obediência, limitando os momentos de prazer que o menino buscava nos jogos e brincadeiras com os amigos de rua. Esse comportamento acaba afastando Jano da própria mulher, Alícia, que sempre marca posição em defesa do filho. Segundo Daiane Pimentel, "O interesse de Mundo pela arte é entendido por Jano como um vício doentio que o atrapalha na vida escolar, social e amorosa.” (PIMENTEL, 2012, p. 9).

Jano é o nome do deus romano representado por uma cabeça de duas faces, uma voltada para o passado e outra para o futuro, relacionando-se às mudanças e transições. A esse respeito, Tassilo Orpheu Spalding (1965) escreve:

Chegado a idade adulta, Jano equipou um navio partiu para a Itália; construiu uma cidade que se chamou Janículo. Tornou-se rei do Lácio. (...) Jano tem dupla face porque exerce seu poder sobre o céu, sobre a terra e sobre o mar; é tão antigo como o mundo. (SPALDING, 1965, p. 142) 
Os projetos econômicos de Jano, na Vila Amazônia e no bairro Novo Eldorado - este em parceria com coronel Zanda -, lembram o aspecto empreendedor do deus romano. Na mitologia, Jano tem poder sobre as iniciações e é o responsável pelo portão dos deuses que se abre ou se fecha aos humanos. Detém ainda a capacidade de olhar para o interior e para o exterior. As duas faces estão representadas, no livro de Hatoum, pela obra criada por Mundo sobre o pai, intitulada História de uma decomposição - Memórias de um filho querido. No último dos quadros, afixados com diversos pregos, eram exibidos dois sapatos de Jano, virados em direções opostas (HATOUM, 2005, p. 293). A figura de Jano encerra o ideal da modernidade capitalista de pretender dominar e transformar todo território, desprezando, em seus propósitos, a vida dos trabalhadores, dos homens comuns e da própria natureza - de onde se extrai tudo de graça. Jano simboliza os homens que são incapazes de observar e ouvir, com atenção, a outridade, a diferença, mesmo quando essa esteja estampada na imagem do próprio filho.

Ao revelar relações espúrias existentes entre capitalistas, políticos e militares, o livro mostra uma alegoria dos pactos existentes entre os poderes hegemônicos no país. Em contraposição, Mundo expõe-se como força incapturável pelos sistemas de poder. Subverte, engana, escapa, mesmo tendo de pagar seus sonhos com a própria vida. Mundo seria um ótimo exemplo para o conceito de artista out-law.

Nesse sentido, o escritor Mário de Andrade pode contribuir um pouco com nossas análises. No último capítulo do livro inacabado intitulado O banquete, escrito durante a Segunda Guerra Mundial e publicado postumamente, ao questionar o próprio projeto de música nacional, Mário assinala que o artista outlaw seria um sujeito consciente de sua função social. Deveria ter a sede de um fazer contínuo e não se "academizar". Nesse sentido, sua postura contra o sistema seria algo visceral, pois incomodaria constantemente o poder político e capitalista vigente. Para Mário, a criação artística não poderia jamais desprezar o processo comunicativo. Isso não significaria a produção de arte simplória "ao alcance do público", ou mesmo de arte exótica para o deleite de certas plateias "indesejadas". (ANDRADE, 1989).

Vale ressaltar que, com o passar do tempo, Mundo vai conseguindo obter maior autonomia artística, maior percepção político-social e sua arte passa a assumir um lugar cada vez mais questionador do status quo. Por outro lado, o seu antigo mentor, Arana, partindo de uma proposta estética pautada pela contracultura - em que arte experimental e social se irmanam -, vai tomando o lugar do artista empreendedor, 
ligado a uma produção - pela ótica de Mário de Andrade - exótica e epidérmica, e diríamos, em total descaso com a preservação da natureza amazônica.

Arana termina por incorporar o diálogo da arte com os mecanismos políticos e econômicos, figurando como artista cooptado pelo sistema. Um bom exemplo dessa questão pode ser vista no painel de Arana encontrado no escritório da construtora administrada por Albino Palha, onde aparecem edifícios na selva e araras sobrevoando uma Amazônia progressista:

Nenhum objeto ou imagem no escritório lembrava a amizade e os negócios com Jano. Ao me virar, vi a parede coberta por um painel pintado com araras. Imensas, sobrevoavam um amontoado de torres de vidro e concreto no horizonte desmatado. A visão alucinada e grotesca da floresta, e talvez do futuro, me arrepiou. (HATOUM, 2005, p. 264).

Cumpre lembrar que, ao contrário de Arana e parecendo reafirmar proposições próximas à do teórico alemão Theodor Adorno, Mundo traz certo tom melancólico em suas cartas, demonstrando a sensação de que a arte estava entrando cada vez mais em um sistema que não se difere muito dos produtos de consumo colocados à venda pelo capitalismo, tornando-se inexoravelmente reificada. Em determinado momento do texto, após citar conversas sobre canções e cinema com o amigo Adrian, em Londres, Mundo confessa, em carta, ao amigo amazonense: "Por Deus, Lavo, o mau gosto assaltou o universo, e a uniformidade vai matar a alma do ser humano." (HATOUM, 2005, p. 246-247). A luta de Mundo é uma luta contra o "Pai". Por empreender uma constante batalha em oposição às instâncias de poder, o artista, mesmo sem consciência clara do que faz, rompe, ultrapassa os limites delineados pelas figuras de Jano - empresário conservador - e Arana - que transita de artista experimental, mestre de Mundo, a mercenário. Arana lembra uma aranha a tecer teias encobridoras, conseguindo, até o final da trama, com a ajuda do narrador, esconder seu verdadeiro papel na história.

\section{Cantos da memória}

Por meio de analogias, falsas pistas, lapsos, intervalos temporais, cruzamento de relatos diversos, o texto vai se configurando, moldado por uma proposta que recebe a contribuição de diversos olhares. Esses vão se entretecendo como em 
um mosaico, um caleidoscópio. O jogo intertextual termina por exemplificar - na superfície textual - o modo como, na realidade, qualquer narrativa se constrói: por meio de "citações", de "arquivos" diversos que são remodelados pela mão do narrador.

A interpolação de cartas e relatos desestabiliza, de certo modo, a unidade autoral da narrativa de Lavo. Mas, em vez de pensarmos que as interpolações na narrativa completam as lacunas da memória, devemos antes percebê-las como a comprovação da impossibilidade de existir uma lembrança completa. Dessa maneira, a heterogeneidade discursiva do livro dialoga com a perspectiva de uma memória fragmentária em oposição à recuperação de uma memória totalizante.

Em A traição de Penélope, Lúcia Castelo Branco assinala que existem dois tipos de texto de memória: aquele em que o sujeito da escrita tenta emendar os fios soltos do vivido e do lembrado, tentando suturar suas fissuras, e outro que exibe a lacuna, a falta, e o texto mostra-nos o lugar fraturado da enunciação do presente e do passado. (CASTELO BRANCO, 1994). O livro de Hatoum parece-nos figurar mais no segundo tipo. Ainda que o autor pudesse ter avançado mais na ideia de incompletude e inacabamento, o texto desconstrói a perspectiva da voz narrativa detentora de toda uma memória do passado que se acredita resgatar de forma inteira.

Uma crítica que se pode fazer ao lugar das cartas e dos relatos no livro é que esses textos quase não alteram o núcleo dos argumentos do narrador, ainda que se mudem os lugares de enunciação. Esse fato configuraria a tentativa do narrador de assegurar o direcionamento final ao enredo. Nesse sentido, Cinzas do norte, mesmo inovando a cena literária, pela conjugação de diversos gêneros e pontos de vista - que às vezes criam alguns posicionamentos diferentes e vão, devagar, construindo o quebra-cabeças textual -, termina por mostrar-se menos inacabado do que poderia ser, pois não assume a polifonia de modo mais radical, com suas falhas, dissonâncias linguísticas, incompletudes e maiores tensões entre os pontos de vista presentes no texto. As diversas modulações de vozes que aparecem, no livro, terminam por reforçar a visão que o narrador deseja imprimir à história. Exemplificando essa questão, assinala Flávia Vicenzi:

As histórias de Ran se harmonizam à narrativa de Lavo, trazendo eventos passados que explicam e ajudam a entender o drama da família Mattoso. A paixão do jovem casal leva a entender o ódio de Jano. O relato de um segundo narrador colabora para que Lavo 
construa a sua análise. Se o sobrinho presencia a perseguição de Jano e o sofrimento de Mundo durante sua adolescência, o tio conta da brutalidade que o menino sofreu na infância. As duas vozes estão em total consenso, mostrando o mesmo ponto de vista. (VICENZI, 2009, p. 28).

Essa percepção a respeito da criação de Milton Hatoum amplia os estudos sobre sua obra. Cumpre, no entanto, lembrar que, mesmo tratando, em Cinzas do norte, de uma pintura incômoda, perturbadora e inacabada como a de Mundo, Milton Hatoum deixa bastante claro, em suas entrevistas e ensaios, que sua proposta literária se vincula claramente à linhagem memorialista proustiana e à tradição machadiana na literatura brasileira; distantes, portanto, de propostas narrativas contemporâneas mais inovadoras. Deve-se ainda salientar a sutileza do autor ao dar a Lavo a profissão de advogado. Esse aspecto não altera a crítica estabelecida acima, mas serviria para justificar um pouco a escolha, feita pelo narrador, de posicionamentos que endossem seus argumentos centrais.

Um importante aspecto a ser ressaltado na leitura do livro é o fato de a família formada por Mundo, Jano e Alícia - sobre a qual Lavo escreve - já estar morta no momento de enunciação. Jeanne Marie Gagnebin (2009) estabelece um diálogo entre túmulo e palavra. A autora mostra como o canto dos poetas épicos configurava-se como forma de lutar contra o esquecimento. Essa era uma "tarefa sagrada" dos poetas, que cantavam a glória dos heróis; tarefa legada aos historiadores, posteriormente. Ao rememorar, o poeta lutava "contra a morte e a ausência pela palavra viva e rememorativa." Desse modo, Gagnebin tece também uma relação entre canto e túmulo, que igualmente representam a luta contra o esquecimento e o reconhecimento do poder da morte. A ensaísta assinala: "O fato da palavra sèma significar, ao mesmo tempo, túmulo e signo é um indício evidente de que todo trabalho de pesquisa simbólica e de criação de significação é também um trabalho de luto." (GAGNEBIN, 2009, p. 45).

Gagnebin ressalta que o canto rememorativo dos poetas tinha como finalidade impedir o esquecimento dos grandes feitos dos heróis, mas conclui, na esteira de Walter Benjamin, que a tarefa do historiador é a de "manter viva a memória dos sem-nome". (GAGNEBIN, 2009, p. 47). Mundo é um desses sem-nome, desses sujeitos desgarrados que vivem a perambular por cidades e países em busca de sonhos, transitando pela vida de modo provocativo, apresentando gestos de dispêndio, doação, invenção. 
Alguns autores relacionam o nome dessa personagem, Raimundo, ao nome da "personagem" presente em O poema de sete faces, de Carlos Drummond de Andrade. A associação faz sentido, levando-se em consideração que Mundo era um gauche na vida, sempre caminhando à esquerda das regras e tradições. Mas outra interpretação, que não exclui esta, também é possível, uma vez que o apelido Mundo prevalece na narrativa. A palavra mundo relaciona-se à ideia de todo, mas acaba não remetendo a ninguém específico. Mundo é todo o mundo, mas também é ninguém. É um sem-nome, sem voz, alguém que se desviou dos caminhos projetados pelo pai - que queria vê-lo como herdeiro dos negócios da família -, buscando cada vez mais uma interação com o conceito de "qualquer um" pensado por Giorgio Agamben (AGAMBEN, 1993). Leiamos a seguinte passagem: "Não posso mais falar. O que restou de tudo isso? Um amigo, distante, no outro lado do Brasil. Não posso mais falar nem escrever. Amigo... sou menos que uma voz..." (HATOUM, 2013, p. 311).

Esse trecho encerra a carta escrita por Mundo a Lavo, e também o próprio livro. Mundo é menos que uma voz, mas ainda assim uma voz que permanece devido ao ato rememorativo do amigo e a fixação de sua memória na palavra escrita. No conhecido ensaio intitulado "O narrador", Walter Benjamin contribui com nossas reflexões ao abordar a questão. Segundo Benjamin, o passado ainda se encontra no presente como conteúdo latente: "O passado traz consigo um índice misterioso que o impele à redenção. Pois não somos tocados por um sopro do ar que foi respirado antes? Não existem, nas vozes que escutamos, ecos de vozes que emudeceram?" (BENJAMIN, 1994, p. 223).

\section{Corpo, corpus}

Durante a narrativa, Mundo revela-se cada vez mais um criador rebelde, ao mesmo tempo engajado, com posicionamentos de esquerda. Sua criação, sua vida e seu corpo trazem intrínsecos diálogos. Sua obra de arte questionadora, não conformista, inacabada, visava a despertar o receptor, não deixá-lo se acomodar diante da realidade. O próprio corpo franzino e doente da personagem estampa-se como lugar fustigado, chocando os olhos de quem o vê. Uma doença contraída na época do Colégio Militar, e que fazia eclodir feridas no corpo, às vezes voltava a aparecer. Provavelmente, essa tenha sido a causa de sua morte precoce, após diversas tentativas de levar adiante a existência gauche. A repressão, a violência, e 
mesmo a tortura, sofridas no âmbito familiar, escolar e militar são transformadas, pelo jovem, em criações artísticas, mas não deixam de se refletir na própria pele. As manchas, as bolhas que surgem no corpo de Mundo são resíduos de uma árdua memória, testemunhas de um difícil percurso existencial. Experiências dolorosas do passado não foram cicatrizadas totalmente.

Torna-se importante ressaltar que o corpo de Mundo figura como receptáculo de diversas formas de repressão, de autoritarismo. Esse dado pode ser percebido, por exemplo, no momento em que Mundo, nu, com um cocar de índio e segurando um remo nas mãos algemadas, exibe-se como um corpo indócil - na perspectiva foucaultiana - na boca de um túnel em Copacabana, ameaçando motoristas e passageiros. Talvez apenas mais uma das performances do artista amazonense, porém vista como desordem ou loucura pelos aparatos de poder que prendem o jovem. (FOUCAULT, 2004).

Segundo Jean Luc-Nancy, "Os corpos são evidentes - e é por isso que justeza e justiça começam e terminam com eles." (NANCY, 1992, p. 42). Ainda de acordo com Nancy, “(...) não há sentido em falar separadamente de corpo e de pensamento, como se cada um pudesse subsistir por si: é que eles são apenas o seu mútuo tocar-se (...)” (NANCY, 2000, p. 36).

De acordo com Daiane Pimentel, “As 'cinzas do norte' são resultado dos trabalhos artísticos de Mundo incinerados por Jano, mas também de vidas e histórias arruinadas pela violência do Estado ditatorial, da família, da sociedade ou de conhecidos." (PIMENTEL, 2012, p. 20). A imagem lembra ainda as cinzas que restam de uma gigantesca floresta que diminui sempre mais devido ao alargamento das fronteiras modernizantes do país.

Das cinzas, do resto, o narrador refaz sua história, sua memória. Cinzas do norte pode ser visto como um trabalho de luto feito por Lavo. Mundo, dessa maneira, poderia representar tantos outros jovens que lutaram contra o sistema sócio-político-econômico no país e acabaram morrendo antes do final da batalha. O livro conta a história da personagem Mundo, que perece, refletindo a própria destruição da natureza do Norte do Brasil, a morte de ideais libertários e utópicos que pautaram a vida de muitos jovens de meados do século XX.

Pode-se estabelecer, na avaliação do livro, a relação entre a autodestruição de Mundo e a decadência física e mesmo a morte de diversos personagens, como Jano e Alícia. Dos tempos radiantes, em que Alícia vivia entre jogos, festas, jantares, amigos importantes, viagens de férias ao Rio de Janeiro, onde comprava novidades 
de luxo, sobraram apenas noites soturnas. Restaram as cinzas dos anos de fulgor do passado. Da posse, da beleza, do fausto, sobraram a decadência física e econômica, o alcoolismo, a solidão. Ao final, até as joias de Alícia são empenhadas para pagar pequenas contas. Como vimos, também a mansão, símbolo maior do prestígio e poder de Jano é destruída. Alícia precisa ainda vender o apartamento do edifício Labourdett e vive seus últimos anos em "uma biboca perto de Copacabana" (HATOUM, 2005, p. 264), acompanhada da fiel empregada Naiá, vinda com ela de Manaus - única herança do passado de glória.

A partir da análise do processo criativo de Hatoum, que toma a memória como matéria, Cinzas do norte deixa de ser apenas a narrativa de Lavo, a história de Mundo, para se tornar "uma tentativa de alegorizar uma fatia da história durante o regime militar" (HATOUM, 2002, p. 16). As memórias de Hatoum daquela noite sombria na década de 70 são diluídas nas vozes de Lavo, Mundo, tio Ran e tia Ramira. As lembranças são ficcionalizadas e recriadas. A retomada literária da vivência do autor nos chamados "anos de chumbo" acaba trazendo certo caráter testemunhal para a obra. Ao escreverem sobre esse período trágico da história do Brasil, pelo viés da intimidade familiar, Hatoum e Lavo fazem o papel do cantor épico de manter a memória; não as dos heróis, mas daqueles que se tornaram menos que uma voz.

Em relação à passagem já citada que assinala o fato de a história de Mundo vir à memória de Lavo "com a força de um fogo escondido pela infância e pela juventude” (HATOUM. 2013, p. 9), cumpre lembrar que Fogo era o nome do cachorro de Jano. Ao final da narrativa, ficamos sabendo que, quando o animal morre - após a morte de Jano e a destruição de sua casa -, sua ossada fora enterrada por Ramira, no quintal da casa da costureira, talvez como índice de um tempo que, mesmo dolorido, se queria preservar na memória. Com a escrita do livro, a história ressurge a partir de vestígios do passado que parecem ter sido desenterrados de um quintal antigo. Ela vem à tona como a força ruidosa de um cão, como sintoma de um drama amoroso, familiar e pessoal, como eco de vozes já emudecidas que lembrando Walter Benjamin - esperam ser ouvidas, de forma reconfigurada, em outra temporalidade.

Na narrativa, percebemos montagens que são estabelecidas - por meio de diversas peças - na tentativa de se entender melhor o passado, o que ainda pulsa, dele, no presente. $O$ trabalho de Lavo como advogado e como escritor relaciona-se à proposta de uma ética da hospitalidade, de abertura ao outro, ao que não se sentiu 
acolhido em sua própria morada, ao estranho/estrangeiro, ao que corre mundo afora, não tendo direito à cidadania, à própria linguagem, às escolhas pessoais. (DERRIDA, 2003).

A morte de Mundo é a morte de um tempo, de um país. Na música Sol de primavera, Beto Guedes e Ronaldo Bastos declaram: "Já choramos muito/ Muitos se perderam no caminho". A canção foi composta em 1979, período em que as campanhas pela anistia acontecem com bastante evidência em território nacional, evocando o desejo de uma nova ordem democrática no país. Bruno Viveiros Martins, ao analisar a canção, afirma: "A lembrança daqueles que ficaram pelo caminho inspira e revigora as forças dos que ainda estavam na batalha não apenas pela liberdade, mas também pela memória dos que se foram." (MARTINS, 2009, p. 123). Para Giorgio Agamben, "dar testemunho significa pôr-se na própria língua na posição dos que a perderam (...).” Agamben, lembrando Hölderlin, assegura que

a palavra poética é aquela que se situa, de cada vez, na posição de resto, e pode, dessa maneira, dar testemunho. Os poetas - as testemunhas - fundam a língua como o que resta, o que sobrevive em ato à possibilidade - ou à impossibilidade - de falar. (AGAMBEN, 2008, p. 160).

Ao contrário da canção do "Clube da Esquina", que vislumbra o sol de um novo tempo, no romance lido, a morte de Mundo desvela a morte de um ideário de esperança e de utopia, acentuando o desencanto com o projeto de modernização do país. No entanto, cumpre lembrar que a última carta de Mundo a Lavo aparece no início e no final da narrativa "lavrada" pelo narrador-personagem. Todas as histórias, lembradas, esquecidas, combinadas e reinventadas por Lavo estão entre as potentes palavras do artista. $\mathrm{O}$ gesto de reuni-las, dar-lhes um sentido revela a tentativa de "traduzi-las", levá-las adiante. Lavo traz, para o âmbito da linguagem, o dom que tia Ramira tinha para alinhavar, costurar, criar vestimentas a partir de dispersos retalhos. Assim, a literatura continua - mesmo lidando com a dor, a perda, o luto - seu intento de dar voz à alteridade; de buscar, entre as cinzas do passado, fagulhas que nos possibilitem entender melhor a realidade presente. 


\title{
Memory traces and sparks of creation in Ashes of Amazon
}

\begin{abstract}
This paper aims to investigate the use of memory concept in the creative process of the novel Ashes of Amazon, from Milton Hatoum. Relations between the author's life and his work are established from the concept of "biographeme" developed by Roland Barthes. Relations between experience, memory, forgetfulness and invention will be discussed, as well as dialogues between literature, memory, body and Contemporary History of Brazil. The structure of the plot of Ashes of Amazon reflects the prospect of fragmentary work with memory. The blend of letters, reports and narrative focus reconfigure more traditional forms of memorialistic genre. However, the speech still holds a connected position, ultimately, to the voice of the narrator, responsible for reorganizing the various texts and genres that alternate in the book.
\end{abstract}

Keywords: Milton Hatoum. Literature. Art. Memory. Politics.

\section{Referências}

AGAMBEN, Giorgio. A comunidade que vem. Tradução de António Guerreiro. Lisboa: Editorial Presença, 1993.

AGAMBEN, Giorgio. Homo sacer: o poder soberano e a vida nua I. Tradução de Henrique Burigo. Belo Horizonte: Ed. UFMG, 2002.

AGAMBEN, Giorgio. O que resta de Auschwitz: o arquivo e a testemunha. (Homo Sacer III). Tradução de Selvino J. Assmann. São Paulo: Boitempo, 2008.

ANDRADE, Mário de. O banquete. Prefácio de Jorge Coli e Luiz Carlos da Silva Dantas. 2. ed. São Paulo: Duas Cidades, 1989.

BARTHES, Roland. Sade, Fourier, Loyola. Tradução de Mário Laranjeira. São Paulo: Martins Fontes, 2005.

BENJAMIN, Walter. Sobre o conceito da história. Magia e técnica, arte e política: ensaios sobre literatura e história da cultura. Tradução de Sérgio Paulo Rouanet. São Paulo: Ed. Brasiliense, 1994. (Obras escolhidas; v. 1)

CAStello BRANCO, Lúcia. A traição de Penélope. São Paulo: Annablume Editora, 1994.

CHIARELLI, Stefania. Vidas em trânsito: as ficções de Samuel Rawet e Milton Hatoum. São Paulo: Annablume, 2007. 
CURY, Maria Zilda Ferreira. "Imigrantes e agregadas: personagens femininas na ficção de Milton Hatoum”. In: DUARTE, Constância Lima; DUARTE, Eduardo de Assis; BEZERRA, Kátia da Costa (Org.). Gênero e representação na Literatura Brasileira. Coleção Mulher \& Literatura. Belo Horizonte: Programa de Pósgraduação em Letras: Estudos Literários, 2002. Vol. II, p. 305-318.

DERRIDA, Jacques. Da hospitalidade: Anne Dufourmantelle convida Jacques Derrida a falar da hospitalidade. Tradução de Antonio Romane. São Paulo: Escuta, 2003.

DIDI-HUBERMAN, Georges. Diante do tempo: História da arte e anacronismo das imagens. Tradução de Vera Casa Nova e Márcia Arbex. Belo Horizonte: Ed. UFMG, 2015.

FOUCAULT, Michel. Vigiar e punir: nascimento da prisão. Tradução de Raquel Ramalhete. 28. ed. Petrópolis: Ed. Vozes, 2004.

GAGNEBIN, Jeanne Marie. Lembrar escrever esquecer. São Paulo: Editora 34, 2009.

HATOUM, Milton. Cinzas do norte. 9. reimp. São Paulo: Companhia das Letras, 2013.

HATOUM, Milton. Entrevista com Milton Hatoum. In: CRISTO, Maria da Luz Pinheiro de (Org.). Arquitetura da memória: ensaios sobre os romances Dois irmãos, Relato de um certo Oriente e Cinzas do Norte de Milton Hatoum. Manaus: Universidade Federal Amazonas, 2007.

HATOUM, Milton. Entrevista. In: MARCELO, Carlos. Milton Hatoum. Correio brasiliense. Brasília: 02 de julho de 2005. Suplemento Pensar, p. 3. In: CHIARELLI, Stefania. Vidas em trânsito: as ficções de Samuel Rawet e Milton Hatoum. São Paulo: Annablume, 2007.

HATOUM, Milton. Um certo Oriente. Letterature D'America. Revista Trimestrale, anno XXII, n 93-94, 2002. ISSN: 1125-1743. Disponível em: http:// www.miltonhatoum.com.br/wp-content/uploads/2010/11/Letterature-DAmerica. pdf. Acesso em: 15 out. 2015

MARTINS, Bruno Viveiros. Som imaginário: a reinvenção da cidade nas canções do Clube da Esquina. Belo Horizonte: Ed. UFMG, 2009.

NANCY, Jean- Luc. Corpus. Tradução de Tomás Maia. Lisboa: Editora Veja, 2000. 
PIMENTEL, Daiane Carneiro. Relato de um certo artista: o testemunho em Cinzas do Norte, de Milton Hatoum. REEL - Revista Eletrônica de Estudos Literários, Vitória, s. 2, ano 8, n. 10, 2012.

PIZA, Daniel. Destinos danados. Entrelivros. São Paulo, n. 5, out. 2005. Disponível em: http://www2.uol.com.br/entrelivros/noticias/destinos_danados. html. Acesso em: 20 nov. 2015

SÁNCHEZ, Yvette. Coleccionismo y literatura. Madrid: Cátedra, 1999.

SPALDING, Tassilo Orpheu. Dicionário de mitologia greco-latina. Belo Horizonte: Livraria Itatiaia, 1965.

VICENZI, Flávia A. de S. Cinzas do norte e a estética modernista. Dissertação de mestrado apresentada ao curso de Pós-graduação em Literatura da Universidade Federal de Santa Catarina. Florianópolis, 2009. Disponível em: https://repositorio. ufsc.br/bitstream/handle/123456789/92776/269439.pdf?sequence=1. Acesso em: 4. jun. 2016

Recebido em 14/07/2016

Aceito em 19/11/2016 